\title{
A Review of Riverbed Extraction and its Effects on Aquatic Environment with Special Reference to Tinau River, Nepal
}

\author{
Khet Raj Dahal, Subodh Sharma and Chhatra Mani Sharma
}

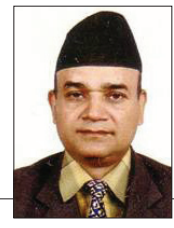

Khet Raj Dahal

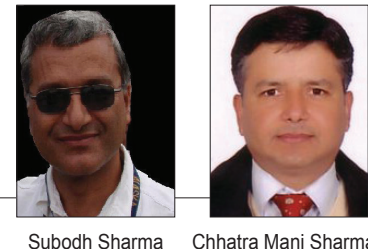

Subodh Sharma Chhatra Mani Sharma

\begin{abstract}
Rivers not only maintain the ecological balance but also generate resources. Fishes and riverbed materials such as sand, cobble, pebble, boulders, etc. are the sources of income from natural rivers; and these are the important resources in the construction industry.

There exist very few studies on the effects of riverbed extraction in the rivers like Tinau. The lack of generic hydrological and climatic data in the river catchment leads to the lack of knowhow regarding the hydrological behavior of the river basin and its consequences over time. This study is the outcome of the literature review on riverbed extraction and its effects on the aquatic environment particularly in the Tinau River. Riverbed extraction can cause many effects on the environment. But this paper mainly focuses on the effects of riverbed extraction on the hydraulic structures, ground water, river morphology, cost externalization, fish species and fisheries for livelihood.
\end{abstract}

Key words: Riverbed extraction, Tinau River, river morphology, cost externalization, aquatic environment, Nepal

\section{A Brief Introduction of the Tinau River}

$\mathbf{T}$ The Tinau, a Class- II category River (Figure 1) flows through the Siwalik Hills and debouches into the Terai Plain at Butwal, Nepal before entering the Indian Territory to join the Ganges.

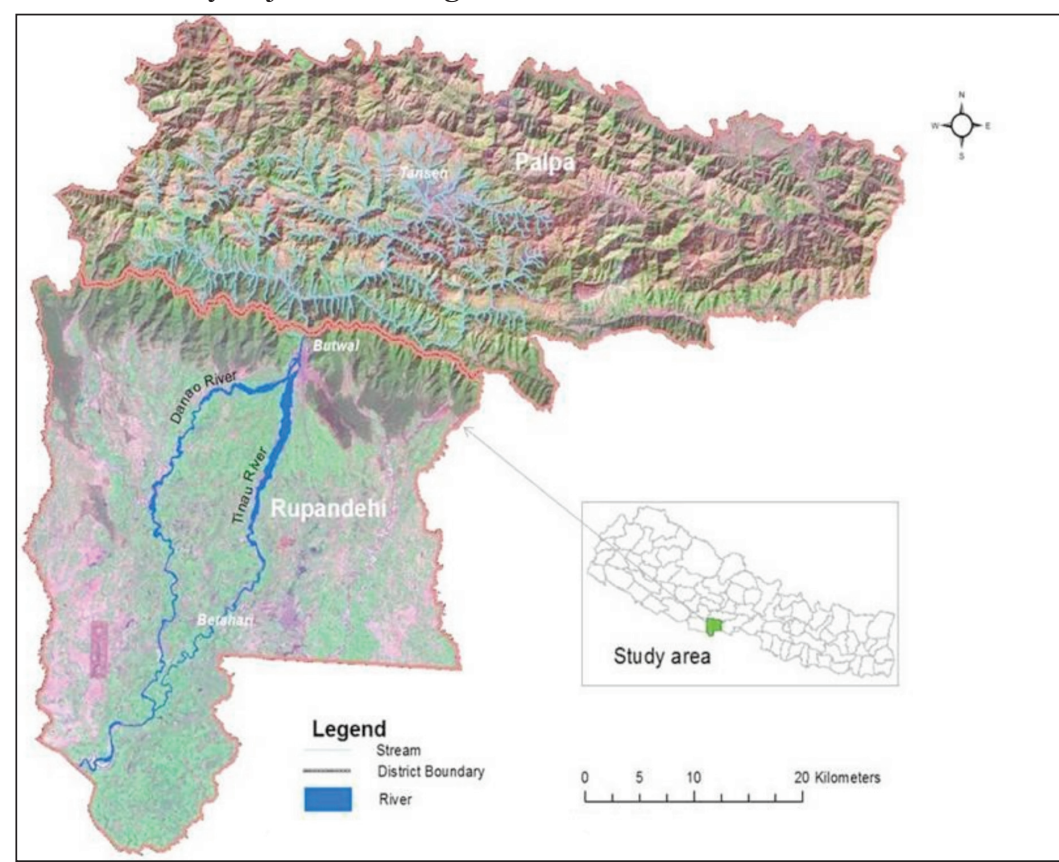

Figure 1. Map Showing Study Area.

The length of this river is about $95 \mathrm{~km}$ from Palpa (source) to the Indo-Nepal Border at Marchawar (Rupandehi), Nepal (Guragain 2012). The width of this River varies from place to place. Generally, the width is very less in upstream and it is larger in the downstream. The total catchment area of the Tinau Basin is 1,081 sq. $\mathrm{km}$ (at the Nepal-India Boarder). The width of the Tinau at the suspension bridge just after debouching from the hills is $75 \mathrm{~m}$ whereas after $1 \mathrm{~km}$ it becomes $110 \mathrm{~m}$. The dry season discharge measured in April is about $2.2 \mathrm{~m}^{3} / \mathrm{s}$, whereas the 100 year (return period) flood discharge is over $2500 \mathrm{~m}^{3} / \mathrm{s}$ (Guragain 2012).
The Tinau is in the degrading stage in the upstream, and it changes its regime to aggrading stage after entering the Terai plain. The deposition of debris from different sources in the Tinau increases when the river flows towards the Terai Plain (especially from Butwal to Bethari about $26 \mathrm{~km}$ downstream from the Highway Bridge on Tinau River at Butwal).

River resources like sand, gravels, cobbles, pebbles and boulders were used by the ancient people in the pre-historic age. This is one of the reasons that many ancient civilizations flourished on the banks of rivers. Butwal at the bank of Tinau River is also considered as one of the ancient cities of this region. The Ramapithecus jaw was found on its bank. Similarly, Butwal is also considered as an old city of commerce and industries. The city provides business services to many districts of the western and mid-western region of Nepal.

Rupandehi District is located nearly at the centre of the national highway (Mahendra Rajmarga). The district has an open border with India on the south. The access roads are available throughout the district. The industrial development of this district is made easy due to the short distance from India. Thus the riverbed materials are easily exported to India. There are many rivers in the districts which are massively exploited beyond their regenerating capacities for riverbed materials. The Tinau, Danao, Rohini, and Kanchan rivers are the examples of such cases.

The Tinau River is being extracted massively since 2004 generating high incomes for the Village Development Committees (VDCs), Municipalities and District Development Committee (DDC) (DWIDP 2011). The income of local bodies (i.e. VDCs, DDCs and Municipalities) is given in Table 1. The data shows that the income was in an increasing trend from 2004/05 to 2009/010. There is a slight decrease in income in the year 2007/o8 which again increased during 2008-2010. 


\begin{tabular}{|l|l|r|r|r|r|r|r|r|}
\hline $\begin{array}{c}\text { S. } \\
\text { No. }\end{array}$ & \multicolumn{1}{|c|}{ Local Body } & $\mathbf{2 0 0 4 / 0 5}$ & $\mathbf{2 0 0 5 / 0 6}$ & $\mathbf{2 0 0 6 / 0 7}$ & $\mathbf{2 0 0 7 / 0 8}$ & $\mathbf{2 0 0 8 / 0 9}$ & $\begin{array}{c}\text { In millions } \\
\mathbf{2 0 0 9 / 1 0}\end{array}$ & $\begin{array}{c}\text { Total } \\
\text { Income } \\
\text { (NRs.) }\end{array}$ \\
\hline 1 & Total (NRs.) & 153.91 & 155.94 & 189.17 & 174.45 & 355.82 & 354.33 & 1383.65 \\
\hline 2 & Equivalent USD (1\$=NRs. 88.39) & 1.729 & 1.752 & 2.125 & 1.960 & 3.998 & 3.981 & 15.548 \\
\hline
\end{tabular}

Table 1. Income Generated by Local Bodies (of Rupandehi district) from the Tinau Riverbed Materials.

\section{Previous Research Focuses on Tinau River}

There have been numerous studies in the Tinau River in diverse aspects. Some of the local organizations involved in the study of the Tinau River are, Tinau Watershed Project, Butwal Municipality, DDC etc. Some other organizations involved in collaborative research are: Japan International Cooperation Agency (JICA), Institute of Development Research (Jaipur, India), Institute for Social and Environmental Transition (Boulder, USA), Madras Institute of Development Studies (Chennai), Nepal Water Conservation Foundation, and Vikram Sarabhai Centre for Development Interaction (India). Besides, some academic studies have also been conducted on this river (Jha 2006; Sharma 1996).

A descriptive Environmental Impact Assessment (EIA) study report was prepared by the DDC (Rupandehi) to continue the extraction activities in the Tinau River. The report has been severely criticized by the environmental experts, stakeholders, and researchers who are directly or indirectly involved in river conservation, particularly in the Tinau River. Despite the criticism, the report consists of some scientific information, especially in respect to biological assessment. The report mentions that the environment of the Tinau River is continuously deteriorating due to water pollution and deforestation. Human activity is one of the main causes for such adverse impacts on the aquatic ecosystem. The extraction has caused a lot of loss of aquatic lives. Thus, the Tinau needs rehabilitation measures such as establishment of restricted areas for extraction of boulders, sand and aggregates from the river (DDC 2011). This clearly underscores the unsustainable the over-extraction status of the river. In 2010, some social activists filed a case in the Supreme Court against the extraction of riverbed materials from the Tinau River. The court ordered to make an EIA report. Thus, the DDC with some hired experts prepared the EIA report. But there was already devastation in the river and it was impossible to extract any more materials from the riverbed or floodplain. The EIA report was made available for public hearing. The general public, social activists and journalists denied passing the EIA report. Thus the report was kept pending (Parliament, 2010). This is the evidence of the general people being concerned at the over extraction of river bed material from the Tinau River.

Sharma (1996) conducted a study on the 'Fish biodiversity and fishery resources of the Tinau River during the period of 1994-1995'. The author selected different stations in the Tinau River from Damkada to
Bethari. During the study, he found 12 fish species at Butwal (Near Siddhababa Temple) station and 13 species at Bethari. The most dominant fish species at Butwal station were Barilius bendelisis (Fageta), Garragotyla (Buduna) and Puntiussophere (Sidre). At Bethari station among 13 species the most dominant species were $P$. conchonius (Sidre) and P. sophere (Sidre). Generally, fish in the Tinau River migrate upstream in the early monsoon (May-June) and migrate in downstream in September-October.

Jha (2006) conducted a research on fish in the Tinau River during the course of his PhD. His study was entitled "Fish ecological studies and its application in assessing ecological integrity of rivers in Nepal". He studied some fish base parameters such as the number of species, composition and the abundance in nine rivers including Tinau. In the case of the Tinau River he found 29 fish species and Catch Per Unit Effort (CPUE) 95.95 .The density of fish species recorded was 23.51 (number/100 $\mathrm{m}^{2}$ ). The study was carried out one decade ago; and at present, the same status of the fishes in the Tinau River cannot be expected due to riverbed extraction; however, scientific data is yet to be collected.

Both Sharma and Jha were focused on finding the fish abundance, species richness of fishes in the Tinau River. The activities of riverbed extraction increased with time; and, ultimately it destructed the fish habitat (WIDP 2011). If the habitat is disturbed, this means that there is loss of fish species and abundance. But the scientific proof is lacking.

Dixit and Gyawali (1999) studied the various uses of water in the Tinau River. As a whole, their study describes the uses of water from the Tinau River and the water management systems throughout the river basin. They mentioned about the deposition in the Tinau River but did not mention about the balanced way of extraction in the Tinau River.

Chhetri (2011) studied the social equity in Chaar Tapaha Irrigation System (3,50o ha) (CTIS) of Rupandehi District. The water in Chaar Tapaha is diverted from the Tinau River. She studied the social justice, water distribution, social norms and values, women's participation in the management, rules and regulation of the Farmer Managed Irrigation System (FMIS), equity in information sharing, equity in cost and benefit sharing, equity in organizational structure, transparency and accountability, equity in wage management, equity in conflict resolution and difficulties in the command area of the canal. The canal is completely farmers managed. 
It had no permanent headwork. Thus the diversion of water into the canal was very difficult. The reason was the deepening of the river bed. Farmers faced this trouble for many years and last year the Department of Irrigation (DOI) made the permanent type of headworks in the Chaar Tapaha Irrigation System. Similarly, DoI constructed a semi-permanent intake system in the Tinau for Soarah Chhatis Mauja Irrigation System (SCMIS).

The People's Embankment Program (PEP 2009) prepared a Detailed Project Report (DPR) in 2009 from Butwal to Marchawar for the conservation of the Tinau River. The study focused mainly on general information of the river hydrology, socio-economic condition of the area, existing condition of the river and proposed remedial measures. The main objective of the program was to construct the required infrastructures on the bank of the Tinau River to prevent the land erosion due to floods. This project is new (started in 2010). The birth of this program is due to the degradation of the river environment. The river bed was extracted massively from 1997 and the bank erosion, river incision and change in morphology of the river took place. The general people were affected by these activities. Thus the government started to build the embankments and other protection measures for the conservation of the river.

Kharel (2002) also studied and prepared a report on 'Description of the Tinau River' which provides only short information related to the Tinau River. But he did not study the effects of riverbed extraction.

The Butwal Municipality (2001) conducted a study on the Tinau River under "Save the Tinau Program". The study was focused on hydrology, geology and geomorphology, river sanitation, irrigation systems, floods and river training works, urbanization and road corridor development of the Tinau River. Since the riverbed extraction is the main problem of the degradation of the river environment, the report describes a little bit in this regard. The riverbed mining is one of the important activities which have been going on over the flood plain and channel of the Tinau River for many years. This activity lowers the riverbed level and increases the bed gradient toward the upstream side. Thus its effects can be seen as increase in the flow velocity and decrease in the discharge of the river. As a result, it leaves behind the non-flooded riverbank (flood plain) like Maina Bagar. Boulder, sand and gravel of the Tinau River are potential sources of construction materials to fulfill the need of Rupandehi as well as its nearby districts. The construction materials from the Tinau River are being exported to India. The undulated riverbed along the course or many man-made ditches, which do not fill up after the main flood, show that there is a clear deficit in sediment deposition as compared to the present mining rate. If the situation continues, there could be a problem of riverbed lowering, which affects riverbank erosion causing damage to the bridge, embankment protection, and intake of the canal in the upstream side. It can also damage all man-made structures (especially hydraulic structures) (Butwal Municipality 2001). Ultimately, the extraction activities incur increased cost for the maintenance SCMIS and CTIS, which is called external cost.

JICA (1999) conducted a study on the flood mitigation plan for selected rivers in the Terai Plain in Nepal. The study covers eight major rivers of Nepal including the Tinau.

The Tinau floodplain extends over 5,700 ha. Its major tree flora is Dalbergia sisso (Sisau), Terminallia tomentosa (Asana), Acacia catechu (Khayar), Ficus glomerata (Bar) and Bombax ceiba (Simal). The principal ground species are Clenodendrum visussum (Bhaat), Cynodon dactydon (Dubo), Ipomoea fistulosa (Ajambari/ behaya), and Saccharum spontaneum (Kansh). This wetland is an important feeding and breeding ground for several aquatic birds including Grus antigon (sarus crane), Egretta alba (Seto Bakulla), Ciconia nigra (Black stork/Kalo Bhundifor), Ibidorhyncha struthensii (Tilhari Chara), Sterna albifrons (Laghu fyalfyale), and Nettapus coromandelianus (Hari Hans) (JICA 1999). JICA has estimated the soil erosion rate of the watershed area of the Tinau River but did not mention about the deposition and debris flow by landslides of the Tinau corridor. Similarly, it did not study about the extraction of riverbed materials and its effects on the aquatic environment.

Paudel (2011) studied the Tinau Basin with a focus on the analysis of floods for different return periods. In addition, he analyzed flood vulnerability and flood risk along the Tinau corridor. But he did not study the effects of riverbed extraction.

\section{Research Gap}

Many organizations and individual researchers have performed different kinds of studies on the Tinau River. However, the studies focusing on Riverbed Extraction and its Effects on the Aquatic Environment, one of the key problems at present time is lacking. Therefore, we hope that this article will help to provide a new insight for the researchers, community based organizations, environmentalists and policy makers.

\section{History of Riverbed Extraction}

Significant riverbed extraction in Nepal for using the raw materials like sand and gravel started since 19631964 (Baidya 2003).

Tinau is one of the richest rivers in sand, gravels and boulders. The history of extraction of this river is very old. But the official record is not available. The massive extraction in the Tinau was begun with the dawn of democracy. The Local Self Governance Act (1999) and Local Self Governance Regulation (1999) provided the local governance bodies the right to use the local natural resources for their development. Thus the extraction of riverbeds to use as raw material was expanded and the local bodies are keeping the record of riverbed extraction since then. 


\section{Effects of Riverbed Extraction}

There are diverse effects of riverbed extraction. Most of the riverbed materials are extracted from the low depth of the river. These are used in the construction of different infrastructures such as road paving, making concrete blocks, building construction etc. The extraction activities destroy the vegetative cover of the aquatic environment and reduce the nutrient inputs into the river.

Riverbed extraction induces lowering of the ground water table, creates disturbance in the aquatic habitat of wetlands, change in river morphology and loss of fish habitat (US-EPA 1995; Trites et al 2009; Scott et al 1999). Other common effects of riverbed extraction are: bank erosion, slope instabilities, river incision, head cutting, and damage to the river equilibrium. Incision of river channel drops the water table in the alluvial banks and it also reduces the storage capacity of an aquifer (Kondolf 1998). Disturbances in the natural rivers and streams are of diverse types which also depend on cultural behavior. However, no attention has been paid towards the cultural disturbances in Nepalese rivers (Khanal 2001). In addition, there are a number of transient effects of riverbed extraction such as noise pollution, air pollution, traffic jam, dust and other emissions, and spill of petrol or diesel on the ground (Kondolf 1998). Generally, in large rivers the quarries are located far from the settlements but in small rivers they may be located near the settlements. Thus the transient effects on the extraction activities are treated as the serious ones. In the case of the Tinau River, there are both types of effects, transient and permanent. But the details of these effects have not been studied yet.

There is high demand of river bed materials across the border for construction of development works such as road construction etc. Export taxes for the river bed materials must be priced considering compensation for the degradation it has caused in the river environment. For example in 2009/10, the revenue collected (for the whole of Nepal) by the local bodies from the river bed extraction was Rs.1 Billion whereas the estimated damage to the road was Rs.11 Billion due to about 23

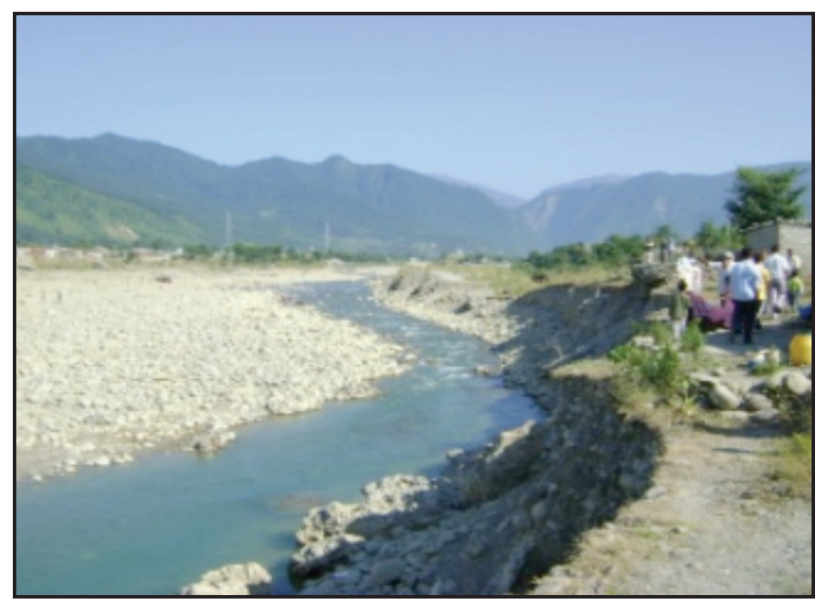

Figure 2. Bank Scouring. tons of truck loads as reported by the Parliamentarian Committee of Nepal.

Riverbed extraction can cause the cost externalization. The profits of riverbed materials are taken mainly by the industrialists, whereas the environmental pollution is left to the dwellers on the bank of the rivers. The place is converted into a nuisance. It is not only harmful to live around the disturbed areas but the aesthetic beauty is also lost. Such effects are found in almost all rivers where the extraction activities are under practice. In the case of the Tinau, the external cost created by the riverbed extraction is yet to be assessed.

In addition to the ecological and cultural aspects, riverbed mining has threatened infrastructures near the rivers (such as bridges, dams and weirs) even in the developed nations (Kondolf et al 1993). Bridges over the Tinau River at Butwal and Bethari are also threatened due to riverbed extraction. However, the extent of this effect has not yet been studied in the Tinau River.

There are various effects of riverbed extraction. Some effects are visible and some are not visible. The general direct effects of gravel extraction are: change in river morphology, impacts on hydraulic structures like dams, spur, revetment wall, culverts and bridges, destruction of fish habitat, loss of livelihoods and cost externalization (Kondolf 1993, 1994, 1997, 1998). These effects can be seen in the Tinau River.

Figures 2, 3, 4, 5 and 6 are the evidences of degradation of the health of the river due to riverbed extraction. Figure 2, shows the bank scouring Figure 3, shows the scour of bridge pier due to extraction; Figure 4 shows the construction of bed bar to prevent further erosion due to extraction; Figure 5 shows the degraded aquatic environment; Figure 6 shows the broken headwork of the canal (built with assistance of the Government of India) at Hattisunde; and Figure 7 shows the damaged spur/river training work due to riverbed extraction.

The illegal and haphazard extraction of riverbed materials is harmful and can damage the overall river environment. Thus the Natural Resources Committee of the Constituent Assembly (CA) recommended extracting the materials after the preparation of an IEE/EIA report

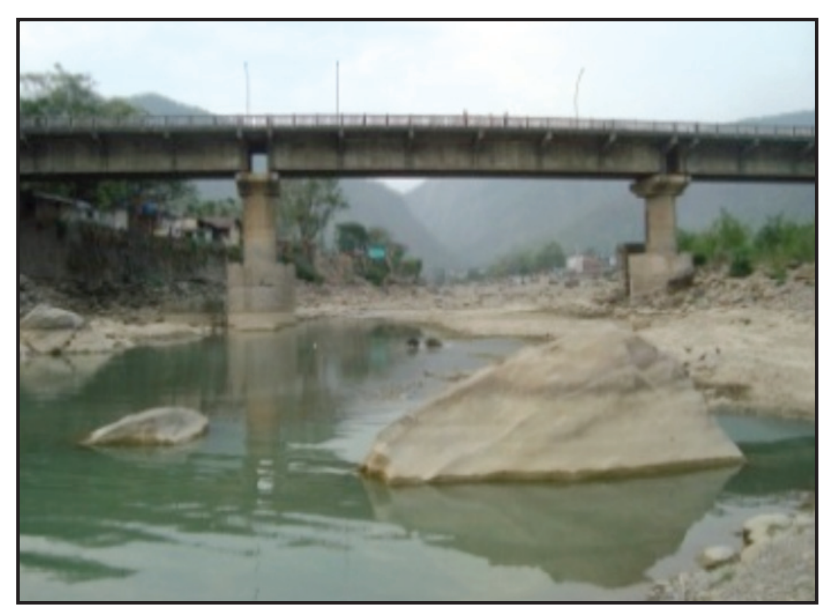

Figure 3. Bridge Pier exposed due to bed Scouring. 


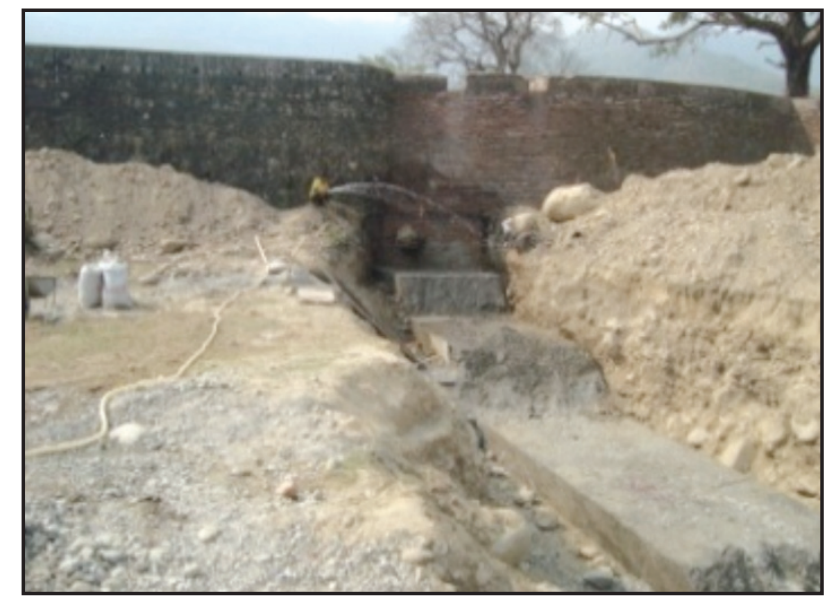

Figure 4. Construction of Bed Bar.

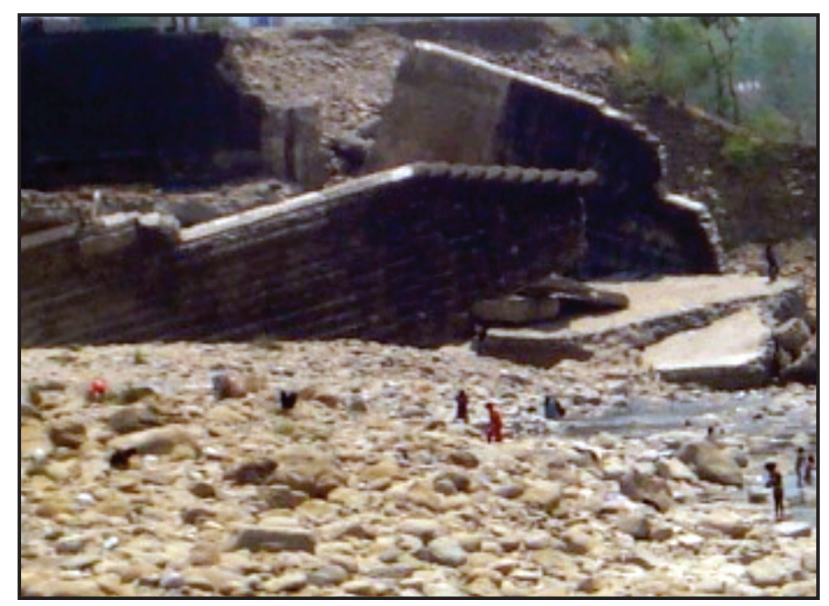

Figure 6. Damaged Headworks.

with a detailed environmental management plan (UNDP 2011).

The natural resources like sand, gravel and boulders are the good sources of income and revenue generation. Many districts of the Terai (15 districts) and some of midhills like Makawanpur, Kavre, Udayapur, Bhaktapur, Kathmandu, Dhading, Kaski and Nuwakot are also the potential districts for riverbed materials. However, it raises the external cost too. The total revenue from the riverbed materials in the last fiscal year (2009/10) was 1 billion, whereas the repair and maintenance cost of the road was 11 billion (UNDP 2011). Thus the cost of road repair and maintenance and other environmental cost must be included while awarding the contract for extracting natural resources.

Butwal Municipality collected more than Rs. 150 million as revenue in the fiscal year 2009/10. The riverbed materials are not only beneficial for revenue collection but also for the overall social development. In some cases, it also contributes to the protection from a catastrophic event. For example, the high flood of Tinau in 2009 was dangerous for Butwal city. If the river would not have been deepened, it could cause the damage of the city including surrounding areas of the river channel (UNDP 2011).

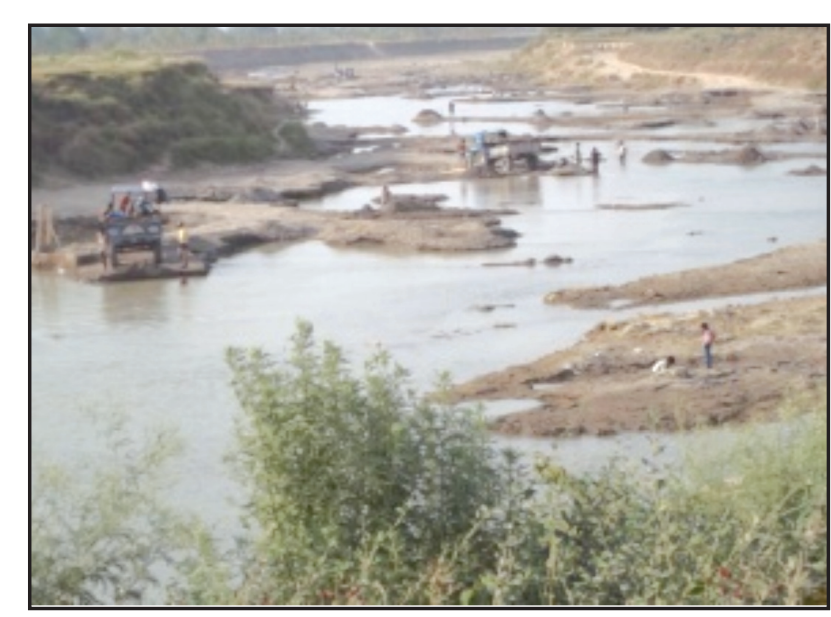

Figure 5. Disturbed Site.

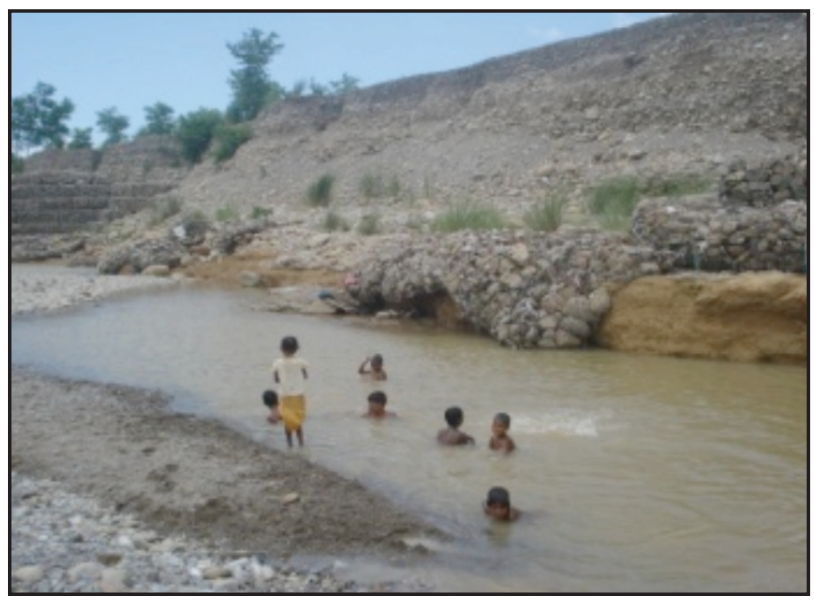

Figure 7. Damaged Spur.

The Tinau River is one of the important rivers to be investigated in terms of ecology and sustainability. This is the heart of Rupandehi District and can attract domestic as well as international tourists. The river could be one of the important tourist destinations, but it has not got considerable priority for development and conservation. At present, this river is generating income for the DDC, VDCs and the municipality by extraction of sand and gravel from the channel and flood plains. The monitoring and evaluating of the health of the river need to be done to prevent the over-stressing the river and keep it healthy. Therefore, to study the overall disturbances of riverbed extraction in the Tinau River, we have to give attention to its ecological as well as cultural aspects. Assessment of impacts on infrastructures should also be given due consideration.

The riverbed materials must be extracted in an environment friendly way. The extraction should be guided by a technical manual. The river warden should be appointed and all resources should be studied in a scientific way (UNDP 2011).

From the literature review and the investigation made by the past researchers, the following problems are caused by the riverbed material extraction in the Tinau (DWIDP 2011; Butwal Municipality 2001; Guragain 
2012; Kharel 2002; Guragain 2012).

- Lowering of the riverbed thereby dangerously scouring the bridge foundation and other hydraulic structures;

- Difficult to divert water from the river for irrigation;

- Negative effects on aquatic life/ fish habitat, livelihoods of fishermen, change in water chemistry/ water quality, and

- Lowering of ground water table.

- Cost externalization

Lowering of riverbed: At the Tinau Bridge in the East-West Highway at Butwal, the bed level has been lowered by about $2.5 \mathrm{~m}$ during the last 15 years. The pier foundation is scoured and became dangerous for the bridge (see photo Figure 3). Further, the floods have damaged spurs, revetment walls etc due to river deepening (DWIDP 2011; Guragain 2012).

Difficult to divert water: Due to deepening of the riverbed of the Tinau, difficulty was faced in diverting water for irrigation by employing the traditional practice of boulder/brushwood dam. Hence the Department of Irrigation (DOI) constructed a semi-permanent diversion structure (cutoff wall) to divert the Tinau water to SCMIS. The same case was with CTIS where DOI constructed a permanent headworks in the Danao too (DOI 2011). Thus four numbers of bed-bars were constructed in the Tinau to divert water into the SCMIS and also CTIS.

Negative effects on aquatic life: In general, riverbed extraction causes the destruction of fish habitat. In the Tinau, the pools have been destructed, and spawning sands, gravels, cobbles, pebbles have been excavated in a massive way. Thus the habitat has been destructed and it has adversely affected the fish habitat in the Tinau (Dahal 2002).

Lowering of ground water table: The extraction activity has lowered the ground water table in the vicinity of the Tinau River. The effects can be seen in many dug wells and shallow tube wells in and around the Butwal area. Many low depth shallows have failed to yield water in the dry season. They yield water only in the rainy season (NEM 2011).

Cost externalisation: The extraction activities have induced lowering of the river bed which has incurred increased cost for the additional maintenance of SCMIS and CTIS Canal, resulting in cost externalization.

All the aforesaid effects of riverbed extraction in the Tinau River need to be researched and proved scientifically in a broad perspective.

\section{Conclusion}

Riverbed extraction can cause the destruction of the whole ecosystem of a river. The extraction activities lower the groundwater table and cause the depletion of productivity. Ultimately, it causes an increase in pollution and causes nuisance to the aesthetic beauty. Extraction of river bed materials directly affects the hydraulic structures like bridges, dams and weirs. The river morphology also changes and incision takes place. Other impacts include the destruction of the aquatic habitat, disappearance of native fish species and invasion of exotic species. As the species and abundance of fish reduces, it affects the livelihood of the people (fishermen). The extraction of riverbed materials benefits the industrialists but it raises the external cost for the general people. More resources need to be made available to save the environment and repair the damaged infrastructures caused by extraction activities.

As river bed extraction is a very good source of income for the local bodies, it is recommended to exploit the resources in a controlled (environmentally sound) manner.

\section{Acknowledgements}

We acknowledge the help of Professor Dr. G. Mathias Kondolf, USA, for providing literature. We are also thankful to Mr. Mahesh Pathak who helped us to make maps in GIS.

Khet Raj Dahal is a PhD scholar of Kathmandu University. He completed his Master of Science in Engineering from the University of Architecture and Civil Engineering, St. Petersburg, Russia, 1993; Master in Sociology from Tri-Chandra College, Tribhuvan University, 1999 and Master of Science in Ecology and Environment from Sikkim Manipal University, 2005. He has been working in different fields of engineering including professional teaching for 20 years. He is the winner in Best writing on environment for the conservation of nature and natural resources from Lumbini Zone in 2005 given by Save the Environment Movement in Rupandehi.

Corresponding address: dahal.khetraj@gmail.com

Subodh Sharma, PhD, is a well-known Professor of Kathmandu University, Department of Environmental Science and Engineering. He completed his PhD from the University of Agriculture, Forestry and Renewable Resources (BOKU), Austria, 1996. He is an expert of Biological Assessment of Water Quality Monitoring, EIA and so many other disciplines associated with hydro-biology. He is interested in conservation of nature and natural resources coupled with researches. He is an author of dozens of scientific research articles. He has been practicing his knowledge in different fields of science and technology including professional teaching.

Corresponding address: sharmaku@yahoo.com 
ChhatraManiSharma, $P h D$, is an Assistant Professor of Kathmandu University, Nepal. He completed his PhD from the Norwegian University of Life Sciences in 2008. He was awarded as an International Young Scientist at the Institute of Tibetan Plateau Research, Chinese Academy of Sciences. He is engaged in many research activities associated with high altitude mountain lakes. He is interested in climate change and is focusing his research towards this direction. Since the past decade he is actively working in research and studies of science and technology including professional teaching. Corresponding address: chhatra.sharma@gmail.com

\section{References}

Arthur, V.B., M.L. Madeleine and B.B. Kristine, 1998, Impacts of gravel mining on gravel bed streams. Transactions of the American fisheries society, 127:979-994.

Baidya, H., 2003, Twelve years struggle for the conservation of Bagmati River. Nepal Water Conservation Foundation, Kathmandu.

Besch, K.W. and Pichettle P. Robert, 1970, Effects of mining pollution on vascular plants in the the Northwest Miramichi River System. Canadian journal of Botany 48:1647-1656.

Boix, C.F. and J.P.M. Vide, 2004, Mathematical model for riverbed degradation due to gravel mining. Technical university of Catalonia, JordiGorina 1-3, D1, o8034 Barcelonia, Spain.

Dahal K. R., 2002, Effects of Tinau Excavation. The Janasangharsha daily, August 29, 2002, Butwal, Nepal.

Bruce Melton, P.E., 2009, Instream gravel mining impacts and environmental degradation feedback associated with gravel mining on the Rio Tigre of the OSA Penunsula, Costa Rica, and the proposed ADI Jimenez Gravel Mining Concession. Report prepared by Melton engineering services, Austin, Texas.

Butwal Municipality, 2001, Save the Tinau. Report prepared by Nepal Engineers' Association, Lumbini Regional Centre, Butwal.

Chhetri, B.K., 2011, Social equity in farmer managed irrigation system (FMIS); A case study of Chaar Tapaha Irrigation System of Rupandehi District. MA Dissertation., the Central Department of Sociology and Anthropology, Tribhuvan University, Nepal.

DWIDP, 2011, Feasibility Study for Tinau Integrated Development Project. Report prepared by Environment and Resource Management Consultant (ERMC) and submitted to Department of Water Induced Disaster Prevention, Kathmandu, Nepal.

DDC, 2011, Environmental Impact Assessment. Draft Report of Tinau, Dano, Rohini and Kanchan Rivers. District Development Committee, Rupandehi, Nepal.

Dixit, A. and D. Gyawali, 1999, Fractured institutions and physical interdependence, challenges to local water management in the Tinau River Basin, Nepal, pp. 58-121 in Rethinking the mosaic, investigations into local water management, Nepal Water Conservation Foundation.

Department of Irrigation (DOI), 2010, Project Report for the construction of head works in Chaar Tapaha and Sorha- Chhatis Irrigation canal.

Dunne, T. and L.B. Leopold, 1978, Water in Environmental Planning. W. H. Freeman and Co., San Francisco, CA.

ENDA- Phosiso Sola, 1996, The Impact Assessment Research Process. Paper Presented at the international workshopon the evaluation of social development, Leeuwenhorrstcongress centre, the Netherlands.

Goodland Robert, 1995, The Concept of Environmental Sustainability. Annual Reviews Ecological System 1995, vol. 26, pp 1-24.

Guragain, H., 2012, Impacts on Hydraulic Structure due to Riverbed Extraction. Thesis Submitted to Lumbini Engineering College, Pokhara University, Nepal.

Hencock, Peter J., 2002, Human Impacts on the StreamGround water Exchange Zone. Environmental Management 29(6): 763-781.

Japan International Co-operation Agency (JICA), 1999, The Study on Flood Mitigation Plan for selected Rivers in the Terai plain in the Kingdom of Nepal, Vol. III. Report, Prepared by Nikken Consultants, Inc., Nippon Koei Co. Ltd.

Jha, B.R., 2006, Fish ecological studies and its application in assessing ecological integrity of rivers in Nepal. Thesis submitted to department of environmental science and engineering. Ph.D. Thesis: Kathmandu University, Nepal.

Khanal, Sanjay Nath, 2001, Effects of Human Disturbances in Nepalese Rivers on the Benthic Invertebrate Fauna. Phd Thesis: University of Agricultural Sciences (BOKU), Vienna.

Kharel, L.N., 2002, Description of the Tinau River. Institute of Engineering, Pulchowk Campus, Tribhuvan University, Nepal.

Kondolf, G. Mathias, 1994, Environmental Planning in Regulation and Management of Instream Gravel Mining in California. Landscape and Urban planning 29 (1994), pp 185-199.

Kondolf, G. Mathias, 1997, Hungry Water: Effects of Dams and Gravel Mining on the River Channels. Environmental Management vol. 21 no. 4, pp 533551.

Kondolf, G. Mathias, 1998, Environmental Effects of Aggregate Extraction from river channels and floodplains. Aggregate Resources a Global perspective, pp 113-129.

Kondolf, G. Mathias, 1993, Geomorphic and Environmental Effects of Instream Gravel Mining. Landscape and Urban planning vol. 28, pp 225-243.

Local Self-Governance Act, 1999, Government of Nepal, Ministry of Law, Justice and Parliamentary Affairs.

Local Self-Governance Rules, 1999, Government of Nepal, Ministry of Law, Justice and Parliamentary 
Affairs.

Morphy, Patrik B., and Robert S. Boyd, 1999, Population status and habitat characterization of the endangered plant, Sarraceniaruba subspecies alabamensis. Castanea 64 (2): 101-101.

Partridge T R, 1992, Vegetation Recovery following Sand Mining on Coastal Dunes at Kaitorete Spit, Canterbury, New Zealand, Biological Conservation 61: 59- 71 .

Parliament (House of Representatives of Nepal), 2010, Decisions collection from the parliamentary committee, committee for the distribution of natural resources, Singh Durbar, Kathmandu, Nepal.

Paudel, Uttam, 2011, Flood plain analysis and vulnerability assessment of Tinau Khola watershed, Nepal. A dissertation submitted to the department of environmental science, T U, Kirtipur.

People's Embankment program (PEP), 2009, Detailed Project Report for Tinau Conservation through the construction of embankment, from Butwal to Marchawar. Ministry of Irrigation, Department of water induced disaster prevention, People's Embankment Programme, Field office, Butwal, Nepal.

Scott, M.L., B. Patrik, F. Shah T. A. and Greeger, 1999, Responses of riparian cottonwoods to alluvial water table declines. Environmental Management 23(3):347-358.

Sharma, C.M., 1996, Study on the fish biodiversity and fishery resources of the Tinau River. M.Sc. Thesis submitted to the Central Department of Zoology, Tribhuvan University, Nepal.

Timothy, M.N., 1993, A Brief History of California's Gold. Cited: http://goldfever.com/ghistory.htm.

Trites, M.B. and E. Suzanne, 2009, Vegetation community in Continental Borea Wetlands along a salinity gradient: implications for oil sands mining reclamation. Aquatic Botany, 91:27-39.

USEPA, 1995, Rapid bioassessment protocols for use in streams and wadeable rivers. United States Environmental Protection Agency.

United Nations Development Programme (UNDP), 2011, A review of current practices of revenue generation from natural resources for the local bodies of Nepal. Ministry of local development, local governance and community development project (LGCDP), Nepal.

WECS, 1987, Erosion and sediment in the Nepal Himalaya. Water and Energy Commission Secretariat (WECS).

\section{Internet Sources}

http://en.wikipedia.org/wiki/Natural_resource. Accessed on 6 Feb. 2012.

http://www.aqa.org.nz/default.asp Accessed on 7 Feb. 2012.

Brennan, C. How products are made: diamond. (http://www.madehow.com/volume-2/Diamond.html Accessed on 15 Feb. 2012.

htpp://www.riverbed_mining_guidelines Accessed on 20 Feb. 2012.

http://icm.landcareresearch.co.nz/research/ research.asp?research_id=6\&theme_id=3 Accessed on 25 Feb. 2012.

http://en.wikipedia.org/wiki/Mass_wasting Accessed on 27 Feb. 2012.

http://en.wikipedia/wiki/Brisbane_River. Accessed on 2 March 2012.

http://www.stevenswater.com Accessed on 12 March 2012.

\section{Hydro Nepal Excellence Award}

This journal has been awarding HYDRO Nepal Excellence Award each year to anyone who has rendered outstanding services in the field of water, energy and/or environment sector. For 2012 award, we had called for suitable nomination for the probable candidates in the HN Journal issue no. 10 (January Issue). However, we have not received any nomination and also the Evaluation and Selection Committee could not find a suitable person/institution for this Award. Hence, no Award has been announced for the year 2012. 